\title{
The role of
}

\section{institutions in \\ local contexts}

\section{Kirsten Appendini}

El Colegio de México,

Mexico City

kirsten@colmex.mx

Monique Nuijten

Wageningen University,

The Netherlands

mnuijten@wxs.nl
This article looks at some methodological issues that confront development research when local institutions are studied. It considers ways of formulating working concepts that are useful for obtaining information on institutions and their dynamic processes in relation to the economic activities of rural households. It presents and evaluates some quantitative and qualitative methods on the basis of case studies in Mexico and India, and considers the scope and limitations of these. The conclusion is that a flexible, multidisciplinary conceptual and methodological framework is needed to understand the dynamics of institutional processes, from established rules and norms to people's organizing practices. It is stressed that policy-oriented research has to focus on specific objectives, such as institutional arrangements capable of supporting the poorest groups, and ways in which these groups can mobilize to transform institutions. 


\section{Introduction}

Institutions have been a focus of the development debate for several decades. With the transformation of the State and recognition of the existence of "market failures", emphasis has been laid on the role of institutions in providing economic and social agents with access to resources and opportunities for enhancing their earning potential. Thus, "getting institutions right" is becoming a dominant policy-making paradigm in the international development agenda. As a result of structural adjustment and economic reform, interventionist policies are giving way to policies that focus on "enabling" and devolving power to populations that are to become active partners in development efforts. With this "bottom up" approach, local institutions have been assigned a central role in the task of helping people cope with the impact of macroeconomic changes and finding new ways to improve their livelihoods through access to employment and resources. Institutions at the local level are seen as mediators that connect macro policies with economic and social agents at the community level, and as a framework that enables people to cope with the "changing ground rules" resulting from structural reform, whether as individuals or collectively.
In this article, we wish to analyse some of the methodological issues confronting development research when local institutions are examined. The study of institutions and the way rural households and individuals interact with their institutional environment raise serious methodological problems to which little attention has been paid in development literature. The present article will consider how relevant information on these subjects can be obtained.

First of all, we briefly analyse how the concepts of "institution" and "organization" are defined and used in development literature. We then discuss how to formulate working concepts that are useful in field research. Lastly, we present and evaluate some quantitative and qualitative methods and the corresponding research techniques, and their potential and limitations for the study of institutions. The argument is illustrated by a number of case studies in which we participated in Mexico and India. ${ }^{1} \mathrm{We}$ believe that the analysis presented here may be of interest both for academic research, including research for policy-making or project- and planning-oriented diagnostic purposes, and for a variety of development agents.

\section{II}

\section{The concept of institutions and organizations in the development debate}

Many development projects assign local institutions a central role in improving the living conditions of the poor. Box 1 shows how a rural family in India and

\footnotetext{
1 The research, which covered cases in India, Mexico and Mozambique, was carried out as part of the Programme on rural household income strategies for poverty alleviation and interactions with the local institutional environment, conducted by the Rural Development Division of the United Nations Food and Agriculture Organization (FAO). The following institutions participated: in India, the Centre for Management in Agriculture, Indian Institute of Management (IIM), Ahmedabad. In Mexico, the Centro Regional
}

another one in Mexico secure their daily livelihoods, and what role institutions play in their lives.

A quick glance at the activities carried out by these two families and the context of these gives an idea of

de Investigaciones Multidisciplinarias, National Autonomous University of Mexico (CRIM/UnAM). In Mozambique, the Department of Plant Production and Protection, Faculty of Agronomy and Forest Engineering, Universidade Eduardo Mondlane, Maputo. We would like to express our gratitude to all these institutions; the opinions expressed here are those of the authors, however, and are their exclusive responsibility. 
Box 1

THE LIFE OF A RURAL FAMILY IN INDIA AND MEXICO

India

The village of Malawada in the district of Kheda, state of Gujarat, is a medium-sized village with a population of 3,000. It has a year-round irrigation channel. Rice and wheat are its main crops. There is also a dairy cooperative and a factory that employs some workers from the village.

Jeevabhai and Ramabhai live in the village of Malawada; they belong to the Parmar caste. The household consists of this elderly couple and one son, his wife and three grandchildren. The household owns four acres of inherited land that is under irrigation; it also has a buffalo and two bullocks. The adults divide their labour between their own land and other properties. They produce a variety of crops, for which they purchase inputs. They also hire labour. Some of their output is sold to the village cooperative. Jeevabhai has been a member of a credit group for 15 years. The women belong to a marketing group for selling milk to a dairy cooperative. The only requirement for membership is to have milk-producing animals. To participate in the credit group, Jeevabhai has to pay a contribution. Membership does not involve a large commitment of time; the members say they have put in one or two days' labour for each organization and do not have an active role in decisionmaking.

Source: IIM (1999).

Mexico

San Pablo is situated in the highlands of the Sierra Juárez in the south-eastern state of Oaxaca. The forest is the main natural resource of the local communities, and is collective property. The community has a complex institutional system of governance that regulates access to and administration of resources.

Pedro, his wife and a granddaughter live in the village of San Pablo. Pedro is a member of the community and owns four plots of land that were allocated to his family some generations ago. The family grows maize and some vegetables for its own consumption, and has four cows. Pedro is entitled to work in the forest, which he does by hiring an outside labourer by the day. In this way he participates in the community forestry enterprise.

In 1964, Pedro was an immigrant worker in California. He now has three married daughters living in Los Angeles, as well as a son working as a mechanic, who regularly sends money home. The family has lent them money to migrate. They are members of a migrants' association. Another two daughters are studying in Mexico City.

Pedro has performed a number of administrative duties (cargos) in local institutions, acting for example as Comisariato (administering common resources) and as secretary, treasurer and trustee of the municipality. He has never received any payment for this work, which is part of his obligations as a member of the community.

Source: CRIM/UNAM/CRUCO/UACH (1999).

the great range of institutions that are important for them (box 2).

As can be seen, a wide range of items are encompassed by the term "institutions". Consequently, the first thing that has to be done is to sort out the concept of "institution" and look for the best way of understanding it in the context of specific research, and then decide how the institutions chosen and their role in the livelihood of each family can be studied.

In order to develop a conceptual framework for the study of institutions in rural contexts, we shall now consider how they have been approached in the development debate. A quick glance at the wider literature shows that there is confusion in the way the concepts of "institution" and "organization" are defined. To begin with, the two terms are often used interchangeably. Furthermore, different disciplines and subdisciplines, such as organization sociology, new institutional economics, economic sociology and anthropology, use these concepts in different ways. Lastly, there is no agreement on their use even within individual disciplines.

Despite the confusion and disagreements, a certain consistency can be distinguished in the use of the terms. Most studies that try to distinguish between organizations and institutions stress the normative aspects of institutions, while laying more emphasis on the structural aspect of organizations. Consequently, 
Box 2

INSTITUTIONS THAT ARE IMPORTANT TO RURAL HOUSEHOLDS, INDIA AND MEXICO

\author{
The caste system \\ The family \\ Marriage \\ Land ownership rights \\ The community \\ Rules, laws and constitutions \\ Water rights
}

\author{
The household \\ The migrants' association \\ The system of indigenous duties (cargos) \\ Local government \\ Labour markets \\ Input and product markets
}

\begin{abstract}
The credit group
The forestry enterprise

The village cooperative

The dairy cooperative

Gender relations
\end{abstract}

organizations are defined more in terms of structures of recognized and accepted roles, while institutions are defined more in terms of the beliefs, norms and rules that make these roles and structures possible (Uphoff, 1986; North, 1990; Ostrom, 1995 and Scott, 1995). The distinction and interconnection between organization and institution can be illustrated with the following example. Schools, the dairy cooperative or the forestry enterprise are organizations that exist because a number of "working rules" or underlying institutions define them and give them meaning. However, institutions such as money, markets, marriage and the law do not have a single, direct organizational manifestation (Leach, Mearns and Scoones, 1997, p. 237). In this article, we shall use the concept of institution in a broad sense that includes not just normative aspects, but also regulatory and cognitive aspects (Scott, 1995). The reason is that many institutions (such as locally developed land tenure arrangements) are more in the nature of customary practices persisting over time than a set of rules or norms (Leach, Mearns and Scoones, 1997, p. 91, and Crowley and Appendini, 1998).

Development projects or policy-oriented research frequently argue that it is important to classify institutions and organizations according to certain criteria. It is often maintained that institutions can be classified as formal or informal. This dichotomy, however, does not make it any easier to grasp the complexity of institutional arrangements in which households are involved. Another distinction that is very often to be found in the literature is the one between grass-roots community organizations, nongovernmental organizations and government agencies (Poulton and Harris, eds., 1988; Curtis, 1991 and Bebbington and Ferrington, eds., 1993). These differences are hard to sustain in practice, however. It is rare for organizations and institutions to be simply public or private, and many successful institutions are a mixture of "private-like" and "public-like" institutions that defies categorization into a sterile dichotomy (Ostrom, 1995, p. 14). Another classification that is often used but is hard to sustain is the one between local and extralocal institutions. It is often difficult to determine whether an institution is local or not, and there does not seem to be much point in laying down strict boundaries. In a context where people are increasingly operating in ways that go beyond specific territorial limits and identities, we would have to find new ways of defining the "local". We argue that the concept "local" alludes to the embedding of larger-scale realities in specific contexts (Appadurai, 1997, p. 55). Thus, when we speak of the local institutional context we are referring to the institutional environment that is relevant to households in the specific geographical areas we are studying.

One problem with much of the literature on local institutions and organizations for poverty relief(Esman and Uphoff, 1984; Korten, 1987; Harris, 1988 and Curtis, 1991) is its reference to collective actions and goals. In fact, most works dealing with "organizations or institutions" for development see institutions as social units whose purpose is to achieve collective goals or meet institutional needs in the society or environment of which they are a constituent part. The concept of the institution as a normative and regulatory structure, however, automatically implies the existence of power differences and divergent interests among the people involved in it. In our study, we see institutions as negotiated orders that are built, sustained and changed by social interaction. Institutions are related to wider configurations of power and domination and may reproduce the ideological and political constraints in which they are embedded. Lastly, it needs to be recognized that institutional and organizational realities are constructed, sustained and altered by processes of cultural creation and enactment. This results in the creation of values and the expression of ideologies, rituals and ceremonies that lead to a sense of 
participation and belonging (see Reed, 1992, pp. 73129).

To obtain a good understanding of the different forms of organization that are important to households, we also used another concept: that of organizing practices. Organizing practices are the different action patterns and strategies that people follow to sustain and develop their daily subsistence and other life projects. A number of anthropologists maintain that rather than starting with the institution, it is more important to begin with the activities of individuals and households. They argue that rural people organize their activities in different ways in their daily lives. Consequently, in many cases organizations are not established, but networks are mobilized to provide crucial information, financial support and practical help (Wolf, 1990 and Long, 1990). This means that attention should be paid to the existence of organizational forms established by the poor before any attempt is made to influence existing institutional environments. These organizing practices are often fragmentary rather than collective in nature. Over time, however, they may develop into ways of ordering and regularities (Nuijten, 1998). When in the course of time these organizing practices become more structured and follow certain implicit rules, we can say that they become institutionalized.

For several reasons, we argue that it is important to pay attention to organizing practices when analysing local institutions. Firstly, structures, which consist more in routine practices than in a set of established rules or regulations, will be identified more easily by studying organizing practices than by focusing on institutions. Secondly, a study of organizing practices can deepen our insight into the ways in which more structured forms may or may not develop. It can also explain why more individualized and fragmented forms of organization often prevail without leading to collective projects. And it can suggest policy recommendations for consolidating certain informal ways of organizing. Thirdly, conflicts and tensions are an important focus of research into organizing practices. This is in contrast with many studies of institutions, which tend to focus on collective functions or goals, or rest on the basic assumption that conflicts will ultimately be resolved through cooperation (neoinstitutionalists, for example). Fourthly, studying organizing practices will preserve us from the tendency to reify institutions and attribute to them roles that they do not have for the people involved.

Consequently, our argument is that if studies focusing on institutions and organizations are combined with others that also look at organizing practices (beginning with the activities of social actors), a better insight can be obtained into the interrelationships between the economic activities of households and local institutions. What we propose is not so much a model as a conceptual framework (see box 3). Having such a

Box 3

CORE CONCEPTS

\section{Institutions}

Institutions consist of cognitive, normative and regulative structures and activities that provide stability, coherence and meaning to social behaviour. Institutions are transported by various carriers - cultures, structures, and routines (Scott, 1995, p. 33).

\section{Organizations}

Organizations are entities set up around defined processes that result in the attainment of particular goals. The structure of an organization is based on the definition of different functions and roles, and its rules must ensure reliable performance (adapted from Scott, 1995, pp. 48-49).

\section{Organizing practices}

Organizing practices are the different actions and strategies that people follow to sustain and develop their daily livelihoods and other life projects. Organizing practices can develop into established patterns (processes of institutionalization) and in this way give rise to the emergence of institutions.

\section{Local institutional context}

The local institutional context is constituted by the specific manifestations of institutions in the geographical area being studied, even though these institutions might extend beyond the physical boundaries of that area. 
flexible framework makes it possible to form a better idea of the role of institutions in the lives of rural people and avoid artificial dichotomies such as the formal/ informal, internal/external, local/extralocal, private/ public and modern/traditional dichotomies. This way, different manifestations of institutions are taken into account and it is easier to deal with heterogeneity and complexity.

\section{III}

\section{Classifying institutions}

Once the research team has an overview of the institutional environment, it is important to classify institutions and organizations in accordance with the objective of the study. Obviously, they can be classified and subdivided in any number of ways. If the study focuses on household income generation, it is important for the classification to be based on access to resources, relations of production or economic activities.

Taking into account the institutions studied, we can arrive at the classification shown in box 4 .

The aim of the classification shown is not to establish exclusive categories but to help develop appropriate strategies for studying and analysing different institutions. Clearly, different types of institution require different types of study and analysis. A caste system cannot be studied and analysed in the same way as a system of land tenure, and a football club cannot be studied in the same way as credit arrangements. Thus, for instance, questions about the year of foundation, main objectives, the number of members or the services supplied to them only make sense in relation to certain organizations and not in relation to other institutions. Where government administrative units are concerned, it does not make sense to speak in terms of membership.

We believe that the four major categories of the classification (main sociocultural divisions, relations of production, local governance, and organizations) need to be dealt with as separate subjects in the final analysis.

A number of the above-mentioned institutions and organizations fall into more than one category. For example, credit groups, cooperative banks, etc., are included among organizations, but they also need to be taken into account when relations of production are considered. The point is that they perform different roles and can be studied from different perspectives (as organizational entities or as part of the credit structure).

Separate consideration needs to be given to production relationships (land tenure, credit and labour relations), as these are complex institutions made up of many different elements.

Again, it is important to have a special category for local governance. This might include the local agencies of government bodies and elected representative groups, such as community councils. These institutions will often be made up of a mixture of public- and private-sector components.

A large number of organizations can be subclassified in different ways. The incorporation of certain criteria allows institutions to be categorized in the way that is most relevant. For example:

- whether the institution includes or excludes certain categories of the population,

- whether the institution focuses on the poor,

- whether the organization has development potential.

Before examining the different methods that might be useful for studying institutions, it is important to pay greater attention to the relationship between local institutions and the productive activities of rural households. It needs to be realized that households operate in multiple institutions at the same time and that it is the combination of institutions that determines demand for and access to resources. ${ }^{2}$ For example, the right to land within a village would be of little use to a household if it were not combined with other institutional arrangements. As we shall see later on, the processes of institutional inclusion or exclusion are also determined by the combined actions of different institutions. Lastly, institutions can overlap and carry out different functions at the same time. This dynamic is illustrated by the examples in the following boxes.

\footnotetext{
2 See Leach, Mearns and Scoones (1997) and Crowley and Appendini (1998).
} 
Box 4

CLASSIFICATION OF THE INSTITUTIONS AND ORGANIZATIONS STUDIED

1. Main sociocultural divisions

- gender relations

- caste relations

- religious alliances

2. Relations of production

- land tenure (rental, sharecropping, ownership)

- credit (lenders, forms of interest, credit groups)

- labour relations (service, mutual assistance, sale of labour in exchange for food)

3. Local government

- ejido/community

- neighbourhoods with committee of elders

- traditional chiefs/authorities

- local government committees

4. Organizations

- Related to production

Directly

Bank of India, district cooperative

Women's production group

Oil producers' cooperative society

Dairy cooperative

Credit groups

Women's saving group

Saving group for the Prajapati caste

Producers' association

- General welfare

Medical posts

Migrant networks, migrants' associations

Subsidized consumer goods stores

Development projects (depending on the type of project)

- Private enterprises

Enterprises

One commercial bank

Tourist company

- Social/religious/educational

Football clubs

Women's groups
Indirectly

Rural agricultural labourer services group Solidarity committees

Non-governmental organizations (NGOs)

Water group maintenance groups $\begin{array}{ll}\text { Youth groups } & \text { Cultural group } \\ \text { Parish/religious groups } & \text { School }\end{array}$ 


Box 5
RECOMMENDATIONS FOR ANALYSING LOCAL INSTITUTIONS
If the purpose of the study is to understand the links between households' income-earning strategies and local
institutions whose focus is on inclusion and exclusion procedures, with a view to policy-making, the following
is recommended for the analysis of local institutions:
- Do not try to present a "complete" picture of local institutions.
This cannot be done, and attempting it would only produce a vague and unfocused outcome.
Do not adhere to artificial classifications.
Most institutions are composed of different elements. They may combine, for example, some characteristics
of public-sector enterprises with others typical of private-sector ones. Exclusive categories should therefore
not be used.
Define the relationship that exists between institutions and socio-economic differentiation.
For example, how access to land differs among the various socio-economic groups.
Determine which institutions merit consideration in development policies.
For example, because they support poor households and have the potential for further development, or
conversely because they are an obstacle to the development of certain households and could perhaps be
altered.

\section{Box 6 \\ HOUSEHOLDS AND THE DYNAMIC OF MULTIPLE INSTITUTIONS}

In the case of the Mexican family, economic activities and access to resources are determined by membership of the community, with the rights and obligations this implies. This means that Pedro participates in local government and resource management institutions. The household is involved with institutions linked to labour and product markets, and with migration support networks. But institutions are not only concerned with economic and local governance activities. Belonging to the community has a broader significance: it is an essential part of a person's life. Rights and obligations are flexible because the members of the community are involved in frequent migration and have created mechanisms so that they do not lose their rights, complying with their obligations even when they are away from the community. Consequently, there may be no direct answer to the question of who has what rights and obligations and when, and land access and use are mediated through other institutions and forms of organizing (Appendini, García and De la Tejera, 2001).

In the case of the Indian family, a number of institutions are important for production activities: land ownership, water management, the labour market, the local input and product markets, the dairy cooperative and the credit groups. Ramabhai can sell milk to the cooperative because his family owns land and can thus provide its animals with fodder. Jeevabhai belongs to a credit group because he owns land, which is a condition of membership. Institutions are also linked here. For example, membership of the dairy cooperative is linked to land ownership and sharecropping agreements (obtaining fodder for animals). For Jeevabhai's son and his family, access to land is connected with relationships of kinship and marriage, since they only have it because they are members of that household.

\section{Box 7}

RELATIONSHIPS BETWEEN RURAL HOUSEHOLDS AND INSTITUTIONS

- Households operate in multiple institutions at the same time.

- It is the combination of different institutions which determines claims and access to resources and the possibility of certain production activities.

- Processes of institutional inclusion and exclusion are the result of the combined working of different institutions.

- Institutions often fulfil different functions at the same time: providing inputs for production activities, providing forms of social security, providing elements which are central to people's identity and meaning in life.

- Institutional integration differs by socio-economic stratum. The institutional linkages of the poorer parts of the population differ from those of the richer parts of the rural population. 


\section{IV}

\section{A discussion of the methodology for studying institutions}

In this section we shall analyse how the study of local institutions should be approached in field research. We suggest that an open, flexible approach needs to be taken, combining qualitative and quantitative methodologies. Taking a critical evaluation of case study experience as our basis, we shall focus mainly on the use of surveys and on qualitative methodologies.

In the case studies, the point of entry to communities was the use of diagnostic techniques based on designs that are very much in vogue among international development organizations and in the project and programme design of government bodies, such as participatory rural appraisal (PRA) and rapid rural appraisal (RRA). The objective of these techniques and similar types of diagnostic is to supply information on the core subjects of the research and the ethnographic context. In the studies carried out in the three countries, PRA/RRA was used to arrive at a general assessment of the community. Information was obtained on the main resources, economic activities and the socio-economic stratification of households, and on the most important institutions.

On the basis of these studies, it was concluded that the PRA was not a powerful enough tool to identify the importance of different institutions. Certain PRA instruments, such as Venn diagrams, tend to have a bias towards organizations, and they exclude less formalized institutions that are often central to household income generation strategies, such as the different arrangements for obtaining credit, reciprocal labour relations and land tenure arrangements. ${ }^{3}$

Some of the lessons learned in this initial phase of the field research were drawn on throughout the study. One of them was the discovery that research cannot always be carried out in a linear fashion, as the research teams need to advance and retreat and be in a position to adapt their research plans when they consider it necessary.

\footnotetext{
3 There is an interesting evaluative literature dealing with the application of these techniques. See Mosse (1994 and 1998); also Richards (1995), cited by Mosse (1998).
}

One of the greatest constraints on policy-oriented research is time. Because there is usually not much time for the field research, detailed data collection is often disregarded. This can result in a faulty diagnosis and bad policy recommendations. Although this is always a dilemma, it can be solved up to a point by well focused research. It is better to concentrate the research on a selected theme than to have a lot of data covering a wide range of themes in little detail. What is needed is not so much to have a broad perspective as to identify clearly and early on in the research what the objectives of the study are in terms of institutions, interests and development intentions. This is crucial for determining the methodology that is to be used and the approach that is required for the research.

Lastly, the experience and qualifications of the members of the research team have a decisive influence on the results. In many countries it is difficult to find highly qualified and experienced research teams. For this reason, the training of such teams can be a goal of the research itself, and of a human resource training strategy -be it local, regional or national-designed to sustain participatory research. It is also important to bring local people into the team and support training for human resources in communities.

We should now like to consider how certain characteristics of institutions and the role they play in the economic strategies of households can be determined using quantitative data obtained from surveys.

A household survey was used to collect quantitative data on institutions associated with income-generating activities, in order to support the material on institutional interrelationships obtained using community appraisals, interviews, cases studies, etc. ${ }^{4}$ Whether or not it is necessary to collect information using questionnaires and, if so, the type of information that is needed, will depend on the specific institutions that are to be studied.

\footnotetext{
${ }^{4}$ The information on households' interrelations with institutions was obtained as part of a broad survey of household income generation strategies.
} 


\section{Box 8}

MeXico: Questions ABOUT RESOURCE-RELATED RIGHTS, OBLIGATIONS AND SANCTIONS

The indigenous community is an overarching institution that encompasses rights to and management of resources by its members, participation in local government bodies, and the obligations and sanctions associated with this.

In the household survey, people were asked about the rules and standards governing access to and use of resources, and about obligations and sanctions.

Access to resources and rights:

\section{Questionnaire}

1. When you become a member of the community, are you as an individual assigned a plot of land to cultivate? - Area of the plot

2. Are you given the right to use common areas?

- Of what kind? (land, common arable land, forest)

3. As a member of the community, are you entitled to participate and vote in the assembly?

4. Do you acquire the right to perform a "cargo"?

5. What "cargo", and in what order of importance?

Access to resources and obligations:

1. Do you have to pay some contribution to the community? What for? How much?

2. Do you have to contribute some labour to the community?

For what purpose? How much? Date of contribution

3. What happens if you leave your plot untended?

4. Are you obliged to attend assemblies? How many times were assemblies held last year? For what purposes were these assemblies held?

5. Did you participate in the assemblies? How many times?

6. Are you obliged to perform a "cargo"? When?

7. Are there any other obligations? What are they?

Sanctions:

1. If you do not comply with your obligations as a member of the community, are you subject to sanctions? What are they?

2. Are the sanctions the same for every type of offence?

3. Are the sanctions the same for a first offence and for repeated offences?

4. If there are rules for access to and use of the forest (for grazing/for cultivation), to what extent are these rules complied with?

5. Where were the sanctions decided on (general assembly; ejido authorities; council of elders; other council; elsewhere - specify)?

6. Who was given responsibility for applying the sanctions?

7. Was there any disagreement about the sanctions? If so, how was it resolved?

Some community rules concerned with resource rights have been relaxed in practice, or are simply not well defined. This is due primarily to migration and to migrants' efforts to retain their rights even though they are away from the community. One example are rights over abandoned arable land. According to Mexican agricultural law, a household loses the right to harvest land that is left untended. But when asked what the consequences would be if a plot were left untended, $69 \%$ of households in the communities studied replied 'nothing would happen'; $17 \%$ replied 'the plot would be forfeited and allocated to another member of the community'; other responses were 'a plot that has been untended for five years or more is forfeited'; 'nothing happens if you hold a "cargo"'; 'nothing happens if the plot is fenced in' (San Pablo); 'if trees are planted on the plot, it becomes part of the community's forest land' (Ixtlán).

Source: $\mathrm{CRIM} / \mathrm{UNAM} / \mathrm{CRUCO} / \mathrm{UACH}$ (1999). 
Data obtained using household surveys can be useful for identifying the institutions that are most important to the different social groups in the community. If the context under study were land tenure relationships, for example, information would have to be collected on the number of households cultivating land under different types of tenure arrangements and on the amount of land cultivated in a given community under each type of contract. If the context were an organization, a credit group say, information would have to be collected on the exact number and type of households participating in it. In most contexts, this participation can be studied in different ways. In the case of a credit group, it can be analysed, for example, in terms of membership of the group, and of credit advanced by the group to different households. This information would have to be reviewed in the light of the household survey and qualitative interviews. In Malan, India, all households have formal access to the dairy cooperative, but only those with access to land and fodder are able to keep cattle and thus produce milk.

Household surveys make it possible to collect a wide range of information on institutional arrangements and practices. They can also include other participationrelated aspects, such as information on rules, rights and obligations (box 8$).^{5}$

In the case of Mexico, it can be concluded that practices in communities differ depending on how decisions are taken about abandoned plots. In San Pablo, where cattle are a major source of income, agricultural plots are not lost if they are fenced in for grazing (privatization); in Ixtlán, some plots are incorporated into the forest for commercial exploitation (collectivization). Different organizing practices do not always adapt smoothly, however, to the changes that take place with time, so that conflict and the erosion of institutions may be part of these processes. Research in this case was based on qualitative information.

\section{V}

\section{Qualitative methods for studying institutions}

As was explained earlier, many of the links between household livelihood strategies and local institutions cannot be understood by means of a diagnostic study with a PRA or RRA or a household survey alone. Other studies are needed. To capture organizing practices and the complex links of the institutional environment within which rural households operate, qualitative research methods are needed (Mikkelsen, 1995). Since qualitative research is time-consuming, only a few institutions can be studied in this way. In any situation, a decision has to be taken as to which institutions are important enough to need studying, and for each of these a special research plan has to be devised. A decision might be taken, for instance, to study institutions whose importance for the activities of certain categories of household has been demonstrated (labour exchange agreements, a cooperative). It can also be useful to make a detailed study of processes that result in certain groups in the population being excluded from an important production organization. If this is done, efforts can be made subsequently to influence these exclusion processes by means of a policy-oriented project. In many situations it will be very important to study the underlying conflicts and tensions in local organizations or in attitudes to land tenure arrangements, before introducing conflict resolution projects or new forms of management.

\section{Some qualitative methods}

There is an enormous literature on qualitative research methods (Strauss, 1987; Silverman, 1993 and Alaasutari, 1995). The following methods are particularly well suited to the study of institutions.

\section{a) Life stories}

Generally speaking, life stories are an efficient way of bringing to light people's efforts and designs for mitigating poverty. They can also be important for the specific study of the institutional contexts in which

\footnotetext{
${ }^{5}$ Of course, participation also has other aspects -participation in decision-making, for instance- that are qualitative and need to be studied differently.
} 
people and households are immersed. Life stories show how household members try to earn a living and meet their different needs, cope with particular uncertainties, and respond to new opportunities and situations by drawing upon different social networks and new forms of organization. In the study of life stories, genealogies can be used as an extra methodological instrument. This can be particularly helpful in areas where there is a great deal of migration and movement, or in areas where migration networks are essential to the household economy. Series of individual and household life histories, combined with the study of resource flows, can help provide an understanding of the relationship between social mobility processes and support networks.

\section{b) Story-telling and the analysis of narratives}

Story-telling is recognized as a key element in the organization process. For this reason, the analysis of stories and narratives is a method which is increasingly being used in the study of organizations. But paying attention to people's personal histories is also important for other reasons. The view that household members take of their own situation and the way people think about themselves and the world around them tell us something about the social and cultural context in which they live and can give us clues to socio-political divisions and forms of inclusion and exclusion related to institutions. This is particularly clear in the study of collective narratives in which what is expressed are not so much individual experiences as the experiences of a social group.

\section{c) Extended case study analysis}

With the extended case study method (Mitchell, 1983 and Walton, 1992) an object of study (event or situation) is chosen to be examined in great detail: for example, the election of the executive board of an organization or the implementation of a new management project. The case study seeks to provide greater detail about social interactions and confrontations, to cast light on institutional processes. As attention is paid to the different groups of people involved, and to the different interests at stake, power relationships and the historical context become central. In this way, extended case studies can reveal dynamics in organizations that go unnoticed when the formal structure of these is examined.

\section{d) Analysis of conflicts and tensions}

Controversial issues, areas of tension and open conflicts are of paramount importance for any analysis of institutions. Situations of conflict cast light on the main resources at stake and the power struggles taking place around them. The study of conflicts reveals how the social actors themselves are organized, how groups form and break up, and what is important to different categories of households. It also shows how the workings of institutions are influenced by power relations, and how official rules, laws and procedures can turn into political instruments and be used as legal resources by individuals and groups to attain their objectives at particular times and in particular places (Starr and Collier, 1989, p. 2).

\section{The use of qualitative methods: examples from Mexico and India}

The Mexican team gave a central place to qualitative research methods, arguing that to analyse the way households were interlinked with local institutions it was necessary to understand the historical context of communities and the dynamic of their economic and institutional changes.

The fundamental principle on which the research was based was that the livelihoods of peasants were grounded in historically developed values and norms that influenced their preferences, knowledge and expectations concerning different productive activities, such as agriculture, animal husbandry and trade. To gain a more thorough understanding of how households' economic strategies were shaped in a dynamic institutional environment, life stories were compiled in selected households.

The results of the survey were used to prepare profiles of households' economies. On the basis of these profiles and of the relationships established with certain people in the early stages of the research, a selection of families was made in each community so that life stories could be constructed. Open interviews were held to reconstruct the way the profile of the household had evolved over the last 30 to 40 years, or even longer in the case of some families. The open interviews were designed to cover households' economic activities and linkages to institutions.

An interpretive approach was used, i.e., attention was paid to the meanings attributed by the peasants themselves to the reality around them. These subjective accounts are essential if the development of local institutions and forms of cooperation is to be understood. They also give an indication of how viable new forms of institution might be. The construction of life stories was carried out in a critical and creative way, 
with a view to filling in gaps and clearing up misinterpretations or inconsistencies, and the peasants were asked to reflect on this. Hence, conditions were created in which people could express themselves quite freely, and a reflective dialogue was established in which it was possible to question stories told at crucial moments.
The qualitative information made it possible to understand different aspects of decision-making and resource management dynamics, including that of the collective forest resources that are of such crucial importance to community and household life. By way of example, box 9 analyses a conflict in the community of San Pablo, Mexico, which had an impact on the

\section{Box 9 \\ ANALYSIS OF INSTITUTIONAL CONFLICTS AND ADMINISTRATIVE PROBLEMS: A COMMUNITY FORESTRY ENTERPRISE (SAN PABLO, MEXICO)}

An independent community forestry enterprise was set up in San Pablo in 1982. The community also has a sawmill. ${ }^{a}$ As in the other forest communities of the Sierra Juárez, control of the forest was legally transferred to the communities after a fierce struggle to end the concessions the Mexican State had granted to private companies.

Formally, communities are supposed to pursue three objectives in forestry enterprises: the reproduction of the household, the interests of the community and the commercial viability of the forestry enterprise.

The first objective is met if the enterprise is able to generate sufficient employment opportunities at pay rates acceptable to workers and owners (the commoners themselves). The second objective requires the enterprise to generate profits that will be used appropriately for the benefit of the whole community (construction of public works, assistance for schools, pensions for widows and the elderly). The third objective requires the enterprise to be developed in a way that ensures democracy, efficiency and sustainability.

The research showed that the technical/organizational needs of forestry activities were incompatible with the day-to-day activities of campesino households. Holidays, migration patterns and maize farming place severe constraints on the operations of the forestry enterprise. For example, it is very difficult to establish steady working routines, organize worker supervision and ensure that the production capacity of the enterprise is used to the full all year round.

There is tension between the need for capital accumulation to sustain and reinvest in the forestry enterprise and the desire to spend profits on public works, religious festivities and redistribution among the commoners. Some commoners prefer direct redistribution of profits to the creation of a common fund to reinvest in the forestry enterprise. Commoners may also prefer to invest in social infrastructure or social security programmes than to reinvest in forestry. If investment is inadequate, the competitiveness of the enterprise and its long-term profitability may decline, and it may become unviable. This tension has created major conflicts in forestry work and political frictions at assembly meetings.

Although it is generally argued that internal conflicts in communities are an obstacle to the development of effective institutions, the research shows that conflict can also give rise to new ideas and viewpoints and create competition among individuals and groups which may speed up institutional adaptation and change.

The research revealed a deep crisis in the community in relation to the forestry enterprise, owing to a fraud committed by the president of the Comisariado de Bienes Comunales (Communal Property Management) in 1988-1989 and the resultant internal feuding among the commoners. This resulted in a long court case and many expulsions from the community. A new group took control, but there is still fundamental discord over the issue of political control of forestry resources. The authorities used the revenues of forestry enterprises to combat rival groups. The conflicts run so deep that every aspect of social life is under serious threat. The commoners meet less and less. Attendance is increasingly being made compulsory, and there is a system of penalties for those who fail to appear. Less effort is now being made to attain consensus. These conflicts have led to splits in the community, and these have left a legacy of doubt about the future running of the enterprise. Most commoners still support the forestry enterprise, however.

Source: $\mathrm{CRIM} / \mathrm{UNAM} / \mathrm{CRUCO} / \mathrm{UACH}$ (1999).

a The community forestry enterprise is run by an operating committee, a director and other professionals. The enterprise is accountable to the Asamblea de Comuneros (Assembly of Commoners), which is officially the highest authority, and to the Comisariado de Bienes Comunales. 
community and even forced a group of inhabitants to emigrate.

The research carried out in San Pablo showed that there were serious contradictions and tensions in the formal objectives of the institution and the relationship with households. The life stories, open interviews and informal talks with local people showed clearly that the different households participating in community forestry enterprises had different ideas about the goals of these enterprises and their own main interests in the project. With the focus on organizing practices, the researchers looked at how the different activities of the community forestry enterprise were conducted day by day. This gave a better insight into organizational processes and the scope for change. Lastly, the researchers focused explicitly on the tensions, problems and conflicts that had arisen, and a conflict analysis was carried out.

In the research in India, a case study was carried out on the dairy cooperative in the community of Malan. The objective of the study was to gain a more thorough

\section{VI}

\section{Conclusions}

This article approaches the debate concerning appropriate methods for dealing with development issues. The conceptual and methodological analysis is intended for people involved in research on rural institutions and poverty reduction. Rural institutions in developing societies operate through complex relationships, among individuals, among households and at other levels. For this reason, our objective is not to dictate a methodological model, but rather to provide insights that can be used to conceptualize and study institutional problems in a flexible way.

Interdisciplinary approaches were used in this project, and methodological pluralism was opted for. The diagnostic studies were supplemented by qualitative and quantitative methods for studying the workings of institutions and their interaction with households. The aims, scope and limitations of each of the methods used were examined. Obviously, there can be many different ways of carrying out field research, and many different analytical approaches to the data collected. understanding of the participation processes and exclusion mechanisms of the households in the cooperative, both for milk delivery and for administrative decision-making (boxes 10 and 11).

The case study in India indicates that the connection among the land, access to fodder, cattle ownership, castes and participation in the cooperative is highly complex. It also shows that the way the cooperative works is related to poverty, a politically sensitive issue in the case being studied. A number of factors prevent many families from becoming actively involved in it. Poor families that can gain access to fodder, and thus can keep animals, are excluded from active participation in the institution's decision-making. The higher castes dominate the cooperative and discriminate against the poor. Discrimination against "untouchables" is still practised in Malan, and class relations are fundamental to power relations and local politics, as it is in all rural areas of Gujarat. It is hard to conceive of democratic processes in contexts where people are unequal.
Two types of conclusions come out of the analysis of methodological issues associated with empirical research into local institutions. Some of them concern the methodology/practice of field studies, while others have to do with the need to achieve a better understanding of local institutions and their interaction with the economic strategies of households, so that policy recommendations can be formulated on the basis of the methodological experience of the cases illustrated.

In the first group, one of the conclusions of the study is that the researcher needs to combine different methods of information collection creatively to cope with the complexity of institutional links in rural societies. The working framework of the research has to be adapted to the specific local conditions of the place where it is conducted.

Another conclusion is that numerous research stages are required, as is the flexibility to adapt field research plans from one moment to the next, as the team judges necessary. 
In the research:

Box 10

QUALITATIVE ANALYSIS OF INCLUSION/EXCLUSION PROCESSES

(Dairy cooperative in Malan, India)

- there were informal discussions with people about subjects related to the cooperative

- cooperative members and non-members were interviewed

- care was taken to interview households of different castes and socio-economic strata

- the managers of the cooperative were interviewed

- people were asked their reasons for being members or non-members

- people were asked why there were different forms of participation and non-participation

- people were asked about the workings of the cooperative, production, services provided, administration and decision-making

- any conflicts and tensions perceived were studied

- cooperative meetings were attended

- people's daily activities were followed up

Source: Rawal (1999).

Box 11

ANALYSIS OF A CASE STUDY

(Dairy cooperative in Malan, India)

The Malan Milk Producer's Co-operative Dairy, in the village of Malan in the state of Gujarat, engages in milk marketing, the sale of cattle fodder and the sale of ghee (clarified butter). The cooperative also acts as a guarantor for members taking out loans to buy cattle. In addition, it provides veterinary services in the village. To be a member of the cooperative, it is necessary to own cattle and deliver milk regularly for a minimum of 90 days. The cooperative has three collection centres in the village for this purpose.

The research showed that participation varied markedly by caste, being much higher among households from the higher Hindu castes than in households from the scheduled castes.

The study identified some of the barriers to participation in the cooperative. Firstly, because Malan is a dry agro-ecological zone, the main requirement for cattle ownership was access to fodder. Access to fodder proved to be closely linked with access to land, which in turn was closely linked to caste.

A number of groups in the village own cattle: the large landowners, from the high Patel caste, have enough fodder and own large numbers of dairy cattle. Those in the second group, who belong to the Rajput caste, own small and medium-sized plots that supply them with enough fodder to feed their cattle. Those in the third group, from the Thaku caste, work as sharecroppers on the lands of the Patel caste, from which they can obtain some fodder for their animals. The fourth group consists of Muslims who own small plots or work as sharecroppers. The fifth group belongs to the Nai caste. These are barbers by trade, and they provide their services to designated individuals belonging to the higher castes (Patel); these services include certain religious rituals, and this gives the Nai the right to certain amounts of grain and fodder from their patrons, so that they can maintain a few head of cattle. The other groups in the village do not own any cattle.

There are also differences as regards members' participation in the cooperative's administration and decision-making. Widespread illiteracy among women and the scheduled castes and the undemocratic working methods of the cooperative were identified as barriers to greater and more active participation by the poor. For example, people who cannot read and write cannot sit on the managing committee. Such people have trouble understanding the proceedings of the general councils, and in the interviews they gave this as a reason for ceasing to attend meetings. Some lower castes have to sit on the floor, even at meetings, when in the presence of the Patel, who treat them with contempt. It is obvious that relationships of this type have an influence on the organization and decision-making processes of the village and of organizations of every kind, including the cooperative.

Source: Rawal (1999). 
In policy-oriented research, there is always a dilemma between time constraints and the quality of the data obtained. This can be resolved up to a point by well focused research.

Lastly, it was found that the training of research teams had to be a key component of research projects. There needs to be a close working relationship between the agencies carrying out the development project or programme, on the one hand, and the research team, on the other. The objectives of training research teams should go beyond the immediate objectives of the development project/programme and be regarded as part of the local/regional/national human resources training effort.

A second consideration relates to conceptual aspects. To obtain and understand information on institutions in a rural environment, it is necessary to have a clear conceptual framework that avoids the rigidities of different theoretical approaches and makes it possible to capture the heterogeneity and complexity of institutional processes. For this reason, we propose a multidisciplinary concept that makes it possible to understand dynamic processes, from established rules and norms to people's organizing practices. Also, we seek to highlight the different levels and categories of institutions referred to in the case studies. Likewise, we stress the need to focus the analysis on certain specific aspects, in accordance with the aims of the research; for example, identifying the institutions that are most important for people's economic activities, processes of inclusion and exclusion, institutional forms that can be altered, improved or constructed for the benefit of poorer groups, and the way these groups can be mobilized to change institutions.

We would like to conclude with some brief remarks regarding examples of policy recommendations that can be drawn from the case studies, on the basis of the conceptual and methodological analysis set forth in this article.

The case of San Pablo is an interesting example of a community that decided to develop a type of local institution that could help it to implement community projects and negotiate with external agents. But it is a case that also shows how difficult it is to set institutional goals that match the income-generating strategies of individual households. The analysis of the forestry enterprise showed that both institutional objectives and institutional procedures could be controversial and problematic. Although these were relatively homogeneous communities from a cultural point of view, the need to take different positions and interests into account prevented the establishment of norms that were acceptable to everybody. There were no clear established ideas regarding the choice between equitable distribution and conservation, or regarding autonomy and dignity. People's ideas about these things depended upon their interests, principles and beliefs, which in turn were related to socio-political forces and the interaction of different views. For the same reason, positions were always flexible and changeable.

Organized into assemblies and discussion groups, a committee has begun the hard work of drawing up plans for common management and for writing up internal rules and procedures. The idea is that the fundamental dilemmas can thereby be dealt with. One policy recommendation that can be drawn from the study is that it would be advisable to establish mechanisms both for resolving conflicts and for solving problems concerning the management of the forestry enterprise.

In the case of India, the research indicated that there were a number of institutions which were important for the economic life of rural communities. Organizations tend to be dominated by the higher castes, however, and a number of adverse mechanisms prevent greater participation by the poorer castes in local organizations. This is the case with the dairy cooperative. As for policy recommendations, one can identify a need for mechanisms to enable poor people to be included more in cooperatives, for example.

This is also related to the need for public policies to operate at a more macro level (through mass literacy programmes and the promotion of better land distribution, for example), to improve the participation and negotiating position of the poorest and most discriminated against.

Concerning policy recommendations, again, the research suggests that it is essential, firstly, to support people's own organizational efforts, even if these are relatively informal in nature (for example, by facilitating certain dealings with bureaucracies or government programmes, or by providing financial support or information); secondly, to introduce programmes or projects that focus on the weakest institutional links, reinforcing them in favour of poor households; thirdly, to provide mechanisms that increase the ability of individual or collective agents to act by themselves so that they can mobilize and/or change institutions for their own benefit; lastly, and this is very important, to provide conflict resolution mechanisms to deal with institutional conflicts that may affect poor households' access to resources. 
When the objective in development programmes and projects is to target certain specific institutions or organizations, it is important to take an open, flexible approach that recognizes local initiatives and considers different groups and interests. This is so that space can be created for open, inclusive negotiations. It is important to identify the areas, ways and levels where action can be taken, since institutions are made up of different components at different levels, ranging from the community and village to government authorities and national legislation. Thus, actions at local level can be linked in with wide-ranging public programmes, such as mass education programmes, which in the end may enhance the prospects of "empowering" poorer groups and hence facilitate a general strategy to increase their participation in local institutions and organizations.

\section{Bibliography}

Alaasutari, P. (1995): Researching Culture: Qualitative Methods and Cultural Studies, London, Sage.

Appadurai, A. (1997): Modernity at Large: Cultural Dimensions of Globalization, Minnesota, University of Minnesota Press.

Appendini, K., R. García and B. de la Tejera (2001): Institutional flexibility in a transnational community: managing collective natural resources, in A. Zoomers (ed.), Land and Sustainable Livelihood in Latin America, Amsterdam, The Netherlands, Royal Tropical Institute.

Bebbington, A. and J. Ferrington (eds.) (1993): Reluctant Partners; Non Governmental Organizations, the State and Sustainable Agricultural Development, London, Routledge.

CRIM/UNAM/CRUCO/UACH (Regional Informatics Centre on Women/ National Autonomous University of Mexico/Centre-West Regional University Centre/Autonomous University of Chapingo) (1999): Estrategias de ingreso en los hogares rurales para alivio de la pobreza e interacciones con las instituciones locales: Caso México, Cuernavaca, Morelos, Mexico, unpublished.

Crowley, E. and K. Appendini (1998): Rural poverty: population dynamics, local institutions and access to resources, paper presented at the Thematic Workshop on Population, Poverty and Environment, Food and Agriculture Organization of the United Nations (FAO)/International Labour Organization (ILO)/ United Nations Population Fund (UNFPA), Rome, October.

Curtis, D. (1991): Beyond Government: Organizations for Common Benefit, London, MacMillan.

Esman, M. and N. Uphoff (1984): Local Organizations: Intermediaries in Rural Development, Ithaca, New York, Cornell University Press.

Harris, M. (1988): On Charities and NGOs, in R. Poulton and M. Harris (eds.), Putting People First: Voluntary Organisations and Third World Organisations, London, MacMillan.

IIM (Indian Institute of Management) (1999): Rural Household Income Strategies for Poverty Alleviation and Interactions with the Local Institutional Environment: A Study of India, Ahmedabad, India, IIM.

Korten, D. (ed.) (1987): Community Management: Asian Experiences and Perspectives, West Hartford, Connecticut, Kumarian Press.

Leach, M., R. Mearns and I. Scoones (1997): Institutions, consensus and conflict: implications for policy and practice, IDS Bulletin, vol. 28, No. 4, Sussex, U.K., University of Sussex, Institute of Development Studies (IDS).

Long, N. (1990): From paradigm lost to paradigm regained? The case for an actor-oriented sociology of development, European Review of Latin American and Caribbean Studies,
No. 49, Amsterdam, The Netherlands, Centre for Latin American Research and Documentation.

Mikkelsen, B. (1995): Methods for Development Work and Research: A Guide for Practitioners, London, Sage.

Mitchell, C. (1983): Case and situation analysis, Sociological Review, vol. 2, No. 31, Oxford, U.K., Basil Blackwell.

Mosse, D. (1994): Authority, gender and knowledge: Theoretical reflections on the practice of participatory rural appraisal, Development and Change, vol. 25, No. 3, London, Institute of Social Studies (ISS).

(1998): Process-oriented approaches to development practice and social research, in D. Mosse, J. Farrington and A. Rew (eds.), Development as Process: Concepts and Methods for Working with Complexity, New York, Routledge.

North, D. (1990): Institutions, Institutional Change and Economic Performance, Cambridge, Massachusetts, Cambridge University Press.

Nuijten, M. (1998): In the name of the land; organisation, transnationalism and the culture of the State in a Mexican ejido, Wageningen, Wageningen Agricultural University, Ph.D. thesis.

Ostrom, E. (1995): Governing the Commons: The Evolution of Institutions for Collective Action, Cambridge, Massachusetts, Cambridge University Press.

Poulton, R. and M. Harris (eds.) (1988): Putting People First: Voluntary Organisations and Third World Organisations, London, Macmillan.

Rawal, V. (1999): Participation of the poor in dairy cooperatives in Gujarat: Studying exclusion in rural institutions, background paper for the project Rural household income strategies for poverty alleviation and interactions with the local institutional environment, Rome, Food and Agriculture Organization of the United Nations (FAO), Rural Development Division, unpublished.

Reed, M. (1992): The Sociology of Organisations; Themes, Perspectives and Prospects, New York and London, Harvester Wheatsheaf.

Richards, P. (1995): Participatory Rural Appraisal: A Quick and Dirty Critique, Notes on Participatory Learning and Action, No. 24, London, International Institute for Environment and Development (IIED).

Scott, W. (1995): Institutions and Organizations, Thousand Oaks, California.

Silverman, D. (1993): Interpreting Qualitative Data: Methods for Analysing Talk, Text, and Interaction, London, Sage.

Starr, J. and J. Collier (1989): History and Power in the Study of Law: New Directions in Legal Anthropology, Ithaca, Cornell University Press. 
Strauss, A. (1987): Qualitative Analysis for Social Scientists, Cambridge, Massachusetts, Cambridge University Press.

UEM (Universidade Eduardo Mondlane) (1999): Estratégias de geração de renda das familias rurais e suas interaccões com o ambiente institucional local, Maputo, Mozambique, UEM, Faculty of Agronomy and Forest Engineering.

Uphoff, N. (1986): Local Institutional Development: An Analytical Sourcebook with Cases, West Hartford, Connecticut, Kumarian Press.
Walton, J. (1992): Making the theoretical case, in H. Becker and C. Ragin (eds.), What is a Case? Exploring the Foundations of Social Inquiry, Cambridge, Massachusetts, Cambridge University Press.

Wolf, E. (1990): Facing Power: Old Insights, New Questions, American Anthropologist, vol. 92, No. 3, Washington, D.C., American Anthropological Association. 